\title{
Risk factor, monitoring, and treatment for snakebite induced coagulopathy: a multicenter retrospective study
}

\author{
Yong Jun Jeon ${ }^{1}$, Jong Wan Kim², SungGil Park², Dong Woo Shin ${ }^{2}$ \\ ${ }^{1}$ Department of Surgery, Chinjujeil Hospital, Jinju, ${ }^{2}$ Department of Surgery, Hallym University Dongtan Sacred Heart Hospital, Hwaseong, Korea
}

Acute and Critical Care 2019;34:269-275.

Corrigendum

https://doi.org/10.4266/acc.2019.00591

In the article entitled "Risk factor, monitoring, and treatment for snakebite induced coagulopathy: a multicenter retrospective study", the IBR approval number was incorrectly presented: IRB No. 2009-01-004-001 should read IRB No. 2019-01-004-001.

Copyright @ 92020 The Korean Society of Critical Care Medicine

This is an Open Access article distributed under the terms of Creative Attributions Non-Commercial License (https:// creativecommons.org/li-censes/by-nc/4.0/) which permits unrestricted noncommercial use, distribution, and reproduction in any medium, provided the original work is properly cited. 